\title{
The Big Naked-backed Bat, Pteronotus gymnonotus, Chiroptera, Mormoopidae, in its northernmost geographic distribution range
}

\author{
Ricardo López-Wilchis ${ }^{1 *}$, Aline Méndez-Rodriguez', Javier Juste²,3, Juan Luís García-Mudarra², Fernando Salgado-Mejia', and Luis Manuel \\ Guevara-Chumacero' \\ 'Departamento de Biología, Universidad Autónoma Metropolitana-Iztapalapa. Av. San Rafael Atlixco 186, Col. Vicentina. 09340. \\ Ciudad de México, México. Email: rlw@xanum.uam.mx (RL-W), aline mera@hotmail.com (AM-R), fesame 33@hotmail.com \\ (FS-M), Imgc@xanum.uam.mx (LMG-C). \\ ${ }^{2}$ Estación Biológica de Doñana, C.S.I.C., Avda. Américo Vespucio 26, 41092. Sevilla, España. Email: juste@ebd.csic.es (JJ), \\ juanele@ebd.csic.es (JLG-M). \\ ${ }^{3}$ CIBER de Epidemiología y Salud Pública, CIBERESP. Madrid, España. Email: juste@ebd.csic.es (JJ), \\ *Corresponding author
}

The Big Naked-backed Bat, Pteronotus gymnonotus, is one of the 15 species currently recognized of this genus, with relatively few specimens in scientific collections, besides being poorly studied. It has a geographical distribution spanning from México through Central America and reaching Perú and Brazil, in which it occupies a variety of habitats from desert to tropical forests below 400 meters above sea level. Here, we report the records that demonstrate its presence, and data about its natural history in southeastern México, the northernmost part of its geographic distribution range. Between June 2002 and July 2018, we captured specimens in 44 bat roosts located in southeastern México, including the Parque Estatal Agua Blanca, Macuspana, Tabasco; Grutas de Martínez de la Torre, Matías Romero Avendaño, Oaxaca; and in Cueva de Villa Luz, Tapijulapa, Tabasco. In the three locations mentioned, we recorded the occurrence of $P$. gymnonotus individuals, whose taxonomic identification at species level was corroborated by both morphological data and genetic analyses. Previously, the only records of $P$. gymnonotus in México were from only four specimens scattered across time, so these new recorded locations confirm the presence of this species in the country. In addition to this, in Agua Blanca State Park and Villa Luz Cave we found a reproductive resident population. The record from Grutas de Martínez de la Torre is located in the middle of the Tehuantepec Isthmus, a well known biogeographical barrier for many taxa in the transitional area to the Pacific lowland's region. We suggest that the occurrence of $P$. gymnonotus in México is also associated with large remnants of evergreen and gallery forests, located in the lowland areas along the Gulf of México and in the north and east of the Tehuantepec Isthmus.

El gran murciélago de espalda desnuda, Pteronotus gymnonotus, es una de las 15 especies actualmente reconocidas del género, de la cual existen pocos registros en colecciones científicas, además de ser poco estudiada. Tiene una distribución geográfica que se expande desde México a lo largo de América Central hasta el Perú y el Brasil, ocupando una variedad de hábitats desde el desierto hasta las selvas tropicales por debajo de los 400 metros sobre el nivel del mar. Se reportan los registros que atestiguan su presencia y datos sobre su historia natural, en el sureste de México, la parte más septentrional de su intervalo de distribución geográfica. Entre junio de 2002 y julio de 2018 capturamos murciélagos en 44 refugios localizados en el sureste de México. Encontramos individuos de P. gymnonotus en tres localidades: el Parque Estatal Agua Blanca, Macuspana, Tabasco; Grutas de Martínez de la Torre, Matías Romero Avendaño, Oaxaca y en la Cueva de Villa Luz, Tapijulapa, Tabasco. La identificación a nivel de especie fue corroborada con datos morfológicos y análisis genéticos. Anteriormente, los registros de $P$. gymnonotus en México correspondían sólo a cuatro ejemplares dispersos en el tiempo, por lo que su registro para estas nuevas localidades confirma definitivamente la presencia de esta especie en el país. Además, en el Parque Estatal de Agua Blanca y en la Cueva de Villa Luz encontramos una población residente reproductivamente activa. El registro correspondiente a las Grutas de Martínez de la Torre se encuentra en el centro del Istmo de Tehuantepec, zona que es bien conocida por ser una barrera biogeográfica para muchos taxones y en la zona de transición a la región de las tierras bajas del Pacífico. Sugerimos que la presencia de $P$. gymnonotus en México también está asociada a grandes remanentes de bosques siempre verdes y de galería, situados en las zonas bajas a lo largo del Golfo de México y en el norte y el este del Istmo de Tehuantepec.

Keywords: Biogeography; geographic distribution; Isthmus of Tehuantepec; México; Mormoopid bats.

๑ 2021 Asociación Mexicana de Mastozoología, www.mastozoologiamexicana.org

\section{Introduction}

The Big Naked-backed Bat, Pteronotus gymnonotus, is a rare and poorly studied species belonging to the Family Mormoopidae. It is one of the 15 currently recognized species of Pteronotus (Pavan and Marroig 2017; Pavan and Tavares 2020). P. gymnonotus is relatively large and heavy, with a forearm length usually measuring 50 to $56 \mathrm{~mm}$. and a body mass between 9.8 to $17.2 \mathrm{gr}$. The rostrum is conspicuously short and broad. It is mainly characterized by its naked back, resulting from its wing membranes meeting on the dorsal midline. The naked-looking rump is covered with very short fur and appears velvety when examined closely. The overall coloration of the upper parts is dark brown, rarely orange, with generally paler underparts; membranes are blackish brown (Smith 1972; Smith 1977; Pavan and Tavares 2020).

Very little is known about its biology and natural history (Pavan and Tavares 2020). P. gymnonotus is an aerial insectivorous bat that roosts exclusively in caves. Generally, this bat occurs at altitudes below $400 \mathrm{~m}$, inhabiting a variety of habitats from deserts, dry and semi-deciduous forests, to savannas and tropical wet forests (Handley 1966; 
Emmons and Feer 1997; Eisenberg and Redford 1999; LaVal and Rodríguez-Herrera 2002; Reid 2009; Pavan and Tavares 2020). In México, it is associated with tropical evergreen high forest (Álvarez-Castañeda and Álvarez 1991a), tropical deciduous forests (Guzmán-Soriano et al. 2013), water bodies and riparian vegetation (Davis et al. 1964; lbáñez et al. 2000).

It is widely distributed in the Neotropical region, with records from southern México (Veracruz) throughout Central America, and south to Perú, Colombia and Venezuela, northeast and central Brazil, Bolivia, and Guyana (Smith 1972; Simmons 2005; Reid 2009; Pavan and Tavares 2020). Although it can be locally abundant in the southern part of its continental distribution, it becomes less abundant and even rare northwards (Smith 1972; Simmons and Conway 2001; Solari 2019; Pavan and Tavares 2020).

Despite its wide geographical range, this species is relatively poorly represented in scientific collections, with only 618 voucher specimens from Central America (Costa Rica, El Salvador, Honduras, Nicaragua, and Panama) and 388 from South America (Brazil, Colombia, Peru, Suriname, and Venezuela) collected between 1901 and 2016 (GBIF 2020). It is categorized as "subject to special protection" by SEMARNAT in México (NOM-059 SEMARNAT-2010) but overall considered as 'Least Concern' according to the IUCN (Solari 2019).

Most of the records for P. gymnonotus in México refer to only single specimens scattered across time. In fact, this species is considered rare not only in México, but also in most of its geographical distribution (Pavan and Tavares 2020). Davis et al. (1964) provided the first record of P. gymnonotus for México based on a single male collected in Cueva Laguna Encantada, Los Tuxtlas, Veracruz. This is its northernmost geographical record, but the species was not recorded again for more than 50 years in spite of subsequent searches made by other authors (Villa-R. 1966; Estrada et al. 1993), including three made by us in March 2005, April 2011 and July 2018. Likewise, Álvarez-Castañeda and Álvarez (1991a) reported one male from Yaxchilan, Chiapas; but its presence in this area could not be confirmed despite the collecting efforts made by Medellín et al. (1986), McCarthy (1987) and Medellín (1993). The species was reported in Tabasco by Ibañez et al. (2000), but prior to that was not found during the intensive field efforts made by Sánchez-Hernández and Romero (1995) and Castro-Luna (1999) in the area, nor later by Castro-Luna et al. (2007). Ibañez et al. (2000) reported the capture of two specimens, a female and a male, from Cueva de Villa Luz, Tapijulapa, Tabasco. Because the female was pregnant, these authors suggested the presence of an undetected reproductive population of $P$. gymnonotus in southeastern México. Finally, the most recent published record of $P$. gymnonotus in México is a single male from El Volcán de los Murciélagos, Calakmul, Campeche, captured in November 2010 (Guzmán-Soriano et al. 2013).

The main objectives for this study were: to report the records that demonstrate the presence of this species in southeastern México. To report two new localities in México, one from the state of Tabasco and the first from the state of
Oaxaca, and to present data about the natural history of this species in the northernmost extent of its distribution.

\section{Methods and Materials}

Study area. We explored caves and some artificial roosts located in Southern México, a region including the states of Campeche, Chiapas, Oaxaca, Quintana Roo, Tabasco, Veracruz, and Yucatan, a low-lying and generally flat region except for the presence of the mountains and hills that make up the Sierra Atravesada, whose highest point "el paso de Chivela" rises to about 250 masl. The area is characterized by a variety of environments with tropical climates which can be humid, sub-humid or semi-dry determined by the presence and amount of rainfall varying from 500 to $4500 \mathrm{~mm}$ and with high temperature variation that oscillates between 15 to $34{ }^{\circ} \mathrm{C}$ (García 1988; Vidal et al. 2007; INEGI 2008). In general, the rains fall with a marked seasonality, clearly distinguishing a dry season from November to April, and a rainy season from May to October (Cavazos and Hastenrath 1990; Santos-Moreno and Ruiz-Velásquez 2007; Lorenzo et al. 2011). The heterogeneity of the landscape includes seven types of vegetation: the upper evergreen and sub-evergreen forest predominate, followed by medium forest (with two variants, sub-deciduous and sub-evergreen) with small areas of low deciduous forest, savannas, aquatic and underwater vegetations, forest gallery, thorny scrub, and xerophilous scrub (IGGUNAM 2007; INEGI 2008).

We prioritized sampling of bats inside and near the Tehuantepec Isthmus region, an area located between the $-94^{\circ}$ and $-96^{\circ} \mathrm{W}$ meridians, which encompasses the states of Chiapas, Oaxaca, Tabasco and Veracruz (Figure 1). It consists of the narrowest land strip that separates the Pacific Ocean from the Gulf of México, spanning only $203 \mathrm{~km}$ (North to South), connecting the North American continent with Central America. This area is characterized by warm and humid climates, a rainy season in the summer, an annual average temperature of around 24 to $27^{\circ} \mathrm{C}$, and precipitation ranging from 1,100 to 2,600 mm (GarcíaRomero 2003; Vidal and Matias 2003; Barragan et al. 2010).

Field trips and sampling. Thirteen field trips were undertaken between June 2002 and July 2018 in search of mormoopid bats. Surveys were conducted during both the dry and rainy seasons, with a mean coverage of three to five nights in each locality. We used mist-nets (Avinet Nylon 30 $\mathrm{mm}$ mesh) and/or harp-traps (standard $4.2 \mathrm{~m}^{2}$ model). The number of harp-traps and mist-nets varied according the characteristics of each site, but most times we used two of each one. The nets were set before sunset as determined by the expected bat flight routes, or trying to cover cave entrances (Kunz et al. 2009) and remained open for 5 to 7 hours. Every night, we took all captured bats regardless of the species, but when a single species had more of 25 individuals, only a representative portion was collected (approximately 10 to 20 specimens) and the rest were immediately released. Those animals were kept separately in soft cot- 


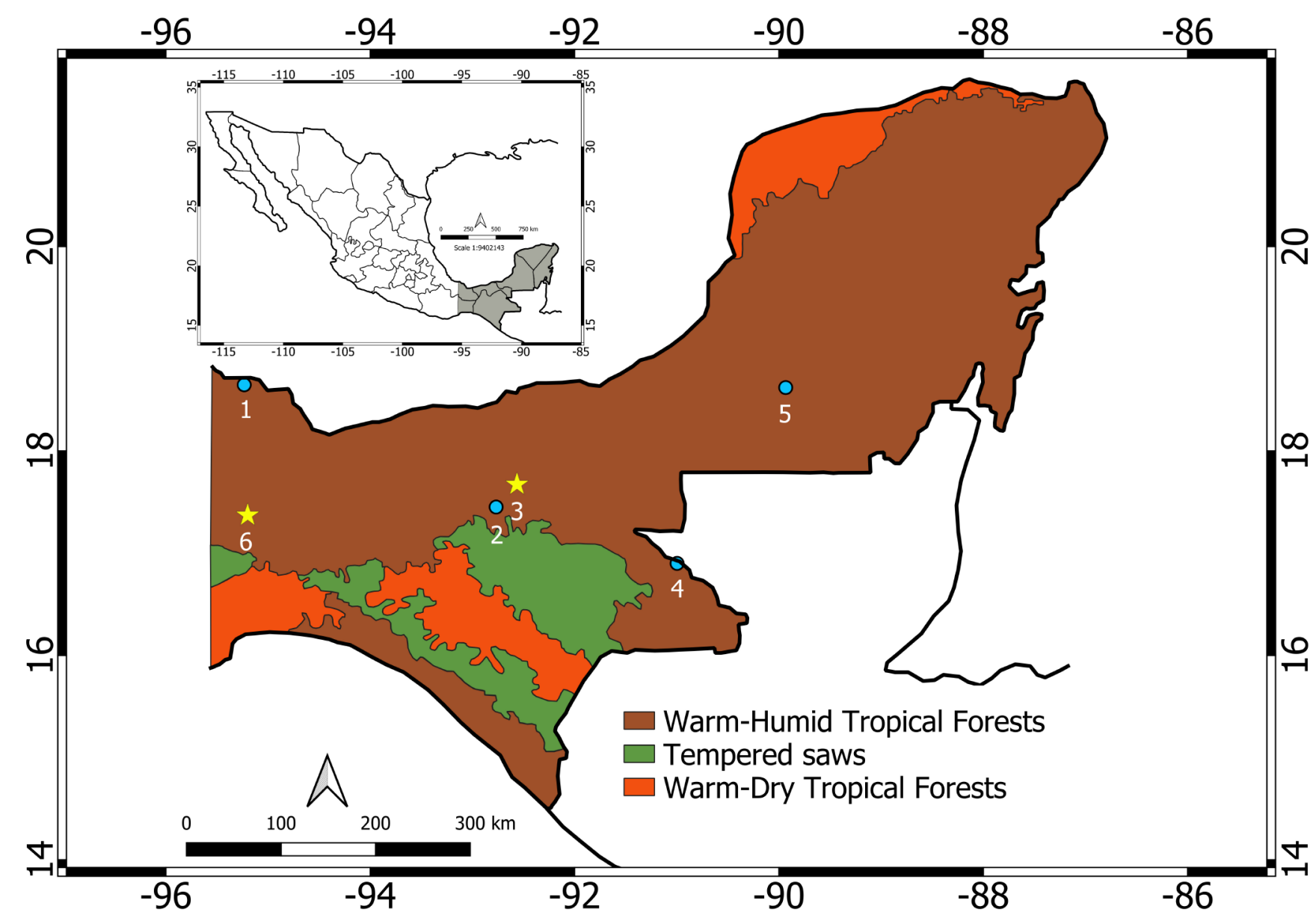

Figure 1. Map with all records known to date for Pteronotus gymnonotus in México 1) Cueva Laguna Encantada. 2) Cueva de Villa Luz. 3) Parque Estatal Agua Blanca. 4) Ruinas de Yaxchilan. 5) El Volcán de los murciélagos. 6) Grutas de Martínez de la Torre. Blue dots indicate previously reported localities, yellow stars the new ones described in this work. The depicted ecoregions were obtained from Atlas de Biodiversidad (CCA, CONABIO, INEGI, INE. 2010).

ton bags for a maximum of three hours and released after recording sex, weight, forearm measurements, and obtaining a biopsy from wing membranes using $3.0 \mathrm{~mm}$ biopsy punches (Fray Products Corp., Buffalo, NY). Tissue samples were stored at $-20^{\circ} \mathrm{C}$ in $70 \%$ ethanol and deposited in the tissue collection of the Laboratorio de Biología y Ecología de Mamíferos de la Universidad Autónoma MetropolitanaIztapalapa (LBEM-UAMI).

Morphological identifications. Pteronotus gymnonotus is easily distinguishable from other species of Pteronotus by its overall size (forearm length of 50 to $56 \mathrm{~mm}$ ) and its naked back formed by its fused wing membranes in the dorsal midline, which are diagnostic characters (Medellín et al. 2008; Álvarez-Catañeda et al. 2017). Within its distribution range in México, P. fulvus is the only other bat species that could be confused with P. gymnonotus, but the former is smaller (forearm length between 41 to $49 \mathrm{~mm}$ ) and much lighter (5 to $10 \mathrm{~g}$; Figure 2).

Genetic identification. Species identification was confirmed using molecular techniques. We performed DNA extraction and amplification of a $607 \mathrm{bp}$ fragment of the gene Cytochrome Oxidase Subunit I (COI) following Lopera-Barrero et al. (2008) and using primers VF1d and VR1d, according to Ivanova et al. (2006). The amplifications were sequenced 3 '-5 'in an ABI PRISM 370xl sequencer. Sequences were edited and aligned in Geneious v. 5.6.4 using the Clustal W algorithm (Kearse et al. 2012) and deposited in GenBank (MK883711, MK883712, MT863621, MT863628). A Bayesian Inference analysis using Mr. Bayes v 3.2 program (Ronquist et al. 2012) was constructed including previously available sequences for $P$. gymnonotus from Guatemala and Panama, as well as sequences for the phylogenetically closest species $P$. fulvus and $P$. davyi. Sequences of $P$. macleayii and $P$. quadridens were used as the external group using the optimal evolutionary model estimated with jModeltest v 2.1.6 considering the Akaike information criterion (Posada 2008). In addition, using the program MEGA v. 5.0.5 (Tamura et al. 2011) and the Kimura 2 Parameters (K2P) model, genetic distances between the sequences of individuals of $P$. gymnonotus, $P$. fulvus, and $P$. davyi were estimated.

Statement of ethics. All bats were collected and handled following the procedures described by the American Society of Mammalogists (Sikes et al. 2016) and our institutional ethical guidelines (Anonymous 2010). Permits to capture and handle the bat species were provided by the Mexican government (SGPA/ DGVS Nos. 05853/13, 09131/14, 003061/18, 9377/19 and CC 08450/92). 


\section{Results}

During the study period, we visited 44 bat roosts (caves, abandoned buildings and sewers, etc.; Table 1). P. gymnonotus was encountered only in three of the explored caves. We recorded $P$. gymnonotus in Parque Estatal Agua Blanca, Macuspana, Tabasco (170 37.20’ N, -92 28.34’ W, 100 masl; Figure 1). This area has a system of caves measuring $5,200 \mathrm{~m}$ in length (Castro-Luna et al. 2007). The climate in this area is humid warm, with a mean annual temperature of $26.8^{\circ} \mathrm{C}$, with rains all year round, and average annual precipitation of 2,614 $\mathrm{mm}$ (Vargas 2012). We visited this locality in March 2005, April 2011, December 2014, and May 2016. During these visits, we captured a total of three males and twenty-eight females. Tissue samples (biopsy) were taken and stored at the LBEM-UAMI with the following registration numbers: 050305Pgy383, 050305Pgy384, 070411Pg1 to $070411 \mathrm{Pg} 7,20141201 \mathrm{Pgym} 1$ to 20141201Pgym16, 20160508PgyH1 to 20160508PgyH4, and 20160508Pgym1, 20160508Pgym2. The individuals of P. gymnonotus were captured late in the night, most of them between 21:00 to 0:30 hrs. Other bat species captured were Balantiopteryx io, Carollia brevicauda, Lonchorhina aurita, Mormoops megalophylla, Natalus mexicanus, Pteronotus fulvus, P. mexicanus and $P$. psilotis.

In July 2018, we captured two specimens of $P$. gymnonotus in Grutas de Martínez de la Torre, Matías Romero Avendaño, Oaxaca (170 22.26’ N, -950 11.98' W; 50 masl; Figure 1). This site is located in northeastern Oaxaca state. It is a cave system surrounded by tropical evergreen forest with warm and humid climate, rainy season in summer and with annual precipitation ranging from $<2,000$ to 2,500 $\mathrm{mm}$ (INEGI 2008). The riparian vegetation is very abundant because a stream emerges from the cave, which joins the Jaltepec River 350 m away. Tissue samples (biopsy) were obtained and deposited in the (LBEM-UAMI), with the registration numbers Pgy23072018m1 and Pgy23072018m2. The bats were two adult males with scrotal testes, and both were collected in a mist net inside the cave at nearly $50 \mathrm{~m}$ from the entrance. They were captured late at night (22:00 and 23:30), with more than one hour difference between them. Other bat species captured were Balantiopteryx plicata, M. megalophylla, P. fulvus, P. mexicanus, P. psilotis, and N. mexicanus.

The other locality in which we captured $P$. gymnotus was the Cueva de Villa Luz, Tapijulapa, Tabasco (170 27.58 'N, $-92^{\circ} 46.75^{\prime} \mathrm{W} ; 80$ masl; Figure 1). This cave is also known as Cueva del Azufre or Cueva de las Sardinas, it includes a main corridor of about $2 \mathrm{~km}$ long and more than 20 short side passages formed by the dissolving action of the stream current. The cave has at least 24 skylights, mostly vertical shafts with dissolution features. It has several chambers, some with vaults up to $15 \mathrm{~m}$ high. However, the passages between the chambers are low. A cave map was published by Hose y Pisarowicz (1999). Its atmosphere contains dangerous concentrations of hydrogen sulfide, carbon monoxide, carbon dioxide, and other harmful gases, in addition to low levels of oxygen; the levels measured exceed the concentrations reported to be toxic for humans. The water, especially that which drips from organic masses known as snottites, is very acidic as well as some springs and streams that are inside the cave. It is a very active ecosystem, based on bacteria that synthesize sulfur and that, contrary to what is expected, allows the existence of a community of several thousand bats (Hose and Pisarowicz 1999; Plath et al. 2006; Guzman-Cornejo et al. 2012). Until now, no study has been carried out to understand how bats can fight against the high concentrations of toxic gases and acid fumes present in the atmosphere. The vegetation of the area corresponds to remnants of a high perennial forest, degraded by the clearings for crop and livestock areas. Riparian vegetation is abundant thanks to the large number of streams. Floristic lists of the cave surroundings area are in Gamboa and $\mathrm{Ku}$ (1998) and Moreno-Jiménez (2019).

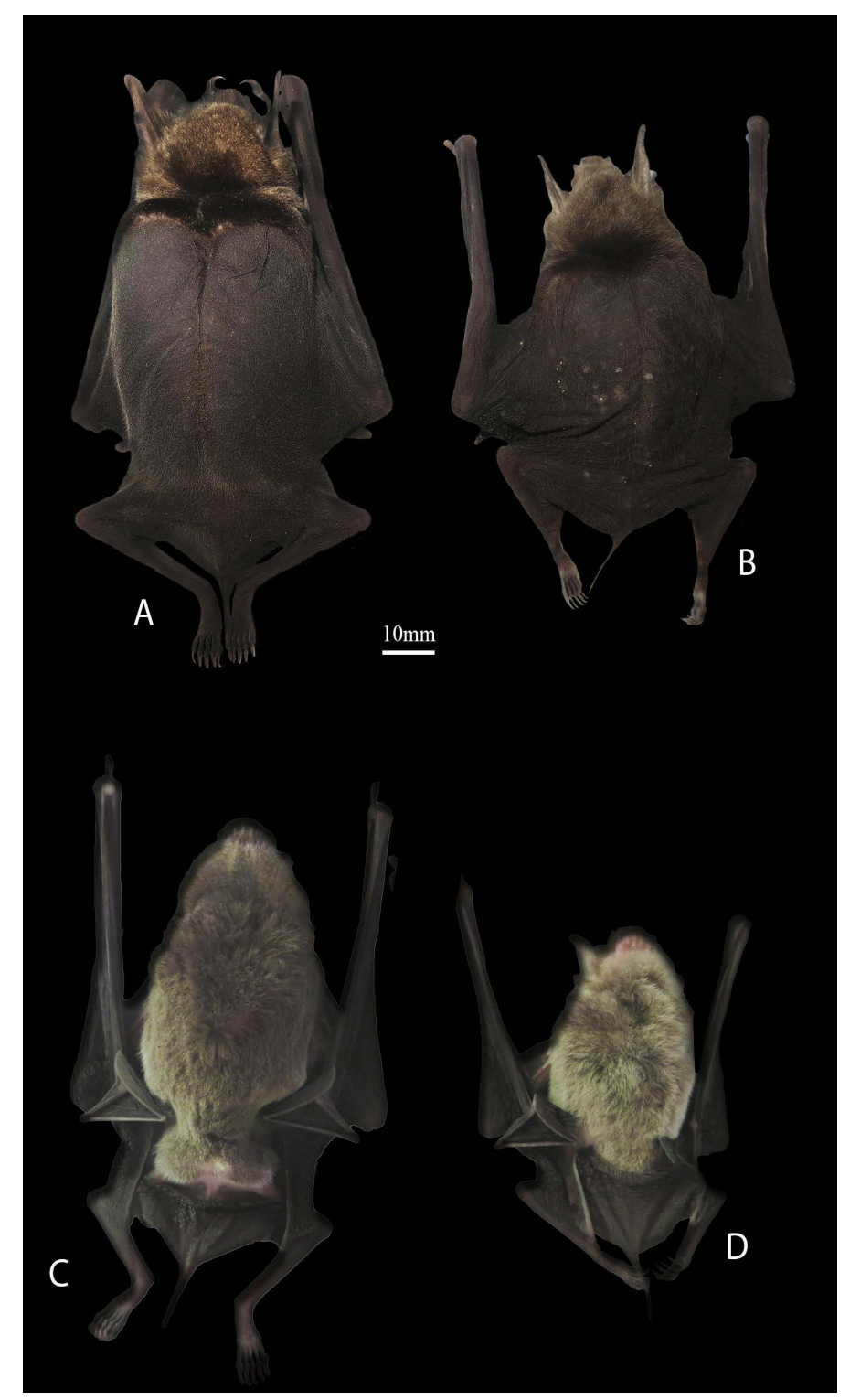

Figure 2. Dorsal and ventral views of an adult female of Pteronotus gymnonotus ( $A$ $C)$ and an adult female of $P$. fulvus (B, D). Both specimens were captured in Parque Estatal Agua Blanca, Tabasco, México on December 01, 2014 
Table 1. Localities sampled in the southeast of México between 2002 and 2018 with their coordinates and arranged in alphabetical order according to the Mexican state, the name of the town and the dates they were visited.

\section{Localities}

Grutas de Xtacumbilxunaán, Bolonchén

Volcán de los Murciélagos, Calakmul

Cueva de Cerro Hueco, Tuxtla Gutiérrez

Cueva de El Aguacero, Ocozocouatla

Cueva de Galicia (El Fresnal), Chicomosuelo

Cueva de Nueva Alianza, Mapastepec

Cueva Lázaro Cárdenas, Tuxtla Gutiérrez

Cueva Los Laguitos, Tuxtla Gutiérrez

Finca la Esmeralda, Huixtla

Grutas de Arcoton, Ejido Artículo 27

Grutas de San Francisco, La Trinitaria

Grutas de Teopisca, Teopisca

Piedra de Huixtla, Huixtla

Alcantarilla, Presa Benito Juárez, Tehuantepec

Cerro Huatulco, Santa María Huatulco

Colonia Cuauhtemoc, Matías Romero

Cueva La Mata, Matías Romero

Grutas de Lázaro Cárdenas, Sto. Domingo Petapa

Grutas de Martínez de la Torre

Guiengola, Tehuantepec

Ojo de Agua, Tolistoque

San Sebastian de las Grutas, Ayoquezco de Aldama

$2 \mathrm{~km}$ al NW Tapanatepec, Tapanatepec

Alcantarilla, Tres Garantías, Othón P. Blanco

Cueva de Kantemó, Dziuché

Cueva Ejido Pedro A. de los Santos

Grutas de Aktun Chen, Akumal

Pueblo Chiclero, Chacchoben

Campus Colegio de Posgraduados, Cárdenas

Cueva de Los Vientos, Tapijulapa

Cueva de Villa Luz, Tapijulapa

Grutas de Coconá, Teapa

Grutas de Cuesta Chica, Tapijulapa

Parque Estatal Agua Blanca, Macuspana

Cueva Arroyo del Bellaco, Pachuquilla

Cueva Boca del Cántaro, Pachuquilla

Cueva Cerro Colorado, Apazapan

Cueva del Vado de la Chachalaca, Apazapan

Cueva Huichapan, Apazapan

Cueva Laguna Encantada, San Andrés Tuxtla

Cueva Sala Seca, Cuitlahuac

Roca del Zopilote, Juchique de Ferrer

Cenote Hoctún, Hoctún

Grutas de Calcehtok, Calcehtok

\section{Coordinates}

Campeche

$19^{\circ} 59.42^{\prime} \mathrm{N}_{-}-89^{\circ} 45.83^{\prime} \mathrm{W}$

$18^{\circ} 31.37^{\prime} \mathrm{N},-89^{\circ} 49.42^{\prime} \mathrm{W}$ Chiapas

$16^{\circ} 73.33^{\prime} \mathrm{N},-93^{\circ} 08.33^{\prime} \mathrm{W}$ $16^{\circ} 04.46^{\prime} \mathrm{N},-93^{\circ} 31.52^{\prime} \mathrm{W}$ $15^{\circ} 43.83^{\prime} \mathrm{N},-92^{\circ} 22.71^{\prime} \mathrm{W}$ $15^{\circ} 25.29^{\prime} \mathrm{N},-92^{\circ} 43.98^{\prime} \mathrm{W}$ $16^{\circ} 53.91^{\prime} \mathrm{N},-93^{\circ} 44.44^{\prime} \mathrm{W}$ $16^{\circ} 49.32^{\prime} \mathrm{N},-93^{\circ} 09.12^{\prime} \mathrm{W}$ $15^{\circ} 19.14^{\prime} \mathrm{N},-92^{\circ} 30.84^{\prime} \mathrm{W}$ $16^{\circ} 16.69^{\prime} \mathrm{N},-91^{\circ} 49.96^{\prime} \mathrm{W}$ $16^{\circ} 05.89^{\prime} \mathrm{N},-92^{\circ} 02.75^{\prime} \mathrm{W}$ $16^{\circ} 38.84^{\prime} \mathrm{N},-92^{\circ} 29.63^{\prime} \mathrm{W}$ $15^{\circ} 11.90^{\prime} \mathrm{N},-92^{\circ} 28.49^{\prime} \mathrm{W}$ Oaxaca

$18^{\circ} 15.49^{\prime} \mathrm{N},-89^{\circ} 02.23^{\prime} \mathrm{W}$ $15^{\circ} 50.59^{\prime} \mathrm{N},-96^{\circ} 21.07^{\prime} \mathrm{W}$ $17^{\circ} 05.04^{\prime} \mathrm{N},-94^{\circ} 52.44^{\prime} \mathrm{W}$ $16^{\circ} 36.82^{\prime} \mathrm{N},-94^{\circ} 57.14^{\prime} \mathrm{W}$ $16^{\circ} 55.40^{\prime} \mathrm{N},-95^{\circ} 15.21^{\prime} \mathrm{W}$ $17^{\circ} 22.26^{\prime} \mathrm{N},-95^{\circ} 11.98^{\prime} \mathrm{W}$ $16^{\circ} 19.73^{\prime} \mathrm{N},-95^{\circ} 15.28^{\prime} \mathrm{W}$ $16^{\circ} 35.19^{\prime} \mathrm{N},-94^{\circ} 52.42^{\prime} \mathrm{W}$ $16^{\circ} 37.83^{\prime} \mathrm{N},-96^{\circ} 58.40^{\prime} \mathrm{W}$ $16^{\circ} 22.16^{\prime} \mathrm{N},-94^{\circ} 11.67^{\prime} \mathrm{W}$ Quintana roo

$18^{\circ} 15.49^{\prime} \mathrm{N},-89^{\circ} 02.23^{\prime} \mathrm{W}$ $19^{\circ} 55.84^{\prime} \mathrm{N},-88^{\circ} 47.46^{\prime} \mathrm{W}$ $18^{\circ} 57.55^{\prime} \mathrm{N},-88^{\circ} 12.35^{\prime} \mathrm{W}$ $20^{\circ} 21.64^{\prime} \mathrm{N},-87^{\circ} 20.50^{\prime} \mathrm{W}$ $19^{\circ} 10.49^{\prime} \mathrm{N},-88^{\circ} 15.20^{\prime} \mathrm{W}$ Tabasco

$17^{\circ} 57.27^{\prime} \mathrm{N},-93^{\circ} 22.54^{\prime} \mathrm{W}$ $17^{\circ} 27.50^{\prime} \mathrm{N},-92^{\circ} 46.40^{\prime} \mathrm{W}$ $17^{\circ} 27.58^{\prime} \mathrm{N},-92^{\circ} 46.75^{\prime} \mathrm{W}$ $17^{\circ} 33.52^{\prime} \mathrm{N},-92^{\circ} 56.07^{\prime} \mathrm{W}$ $17^{\circ} 26.49^{\prime} \mathrm{N},-92^{\circ} 45.54^{\prime} \mathrm{W}$ $17^{\circ} 37.20^{\prime} \mathrm{N},-92^{\circ} 28.34^{\prime} \mathrm{W}$ Veracruz

$19^{\circ} 13.32^{\prime} \mathrm{N},-96^{\circ} 38.34^{\prime} \mathrm{W}$ $19^{\circ} 13.78^{\prime} \mathrm{N},-96^{\circ} 38.24^{\prime} \mathrm{W}$ $19^{\circ} 21.21^{\prime} \mathrm{N},-96^{\circ} 41.77^{\prime} \mathrm{W}$ $19^{\circ} 20.25^{\prime} \mathrm{N},-96^{\circ} 39.28^{\prime} \mathrm{W}$ $19^{\circ} 21.35^{\prime} \mathrm{N},-96^{\circ} 41.97^{\prime} \mathrm{W}$ $18^{\circ} 27.71^{\prime} \mathrm{N},-95^{\circ} 11.18^{\prime} \mathrm{W}$ $18^{\circ} 50.00^{\prime} \mathrm{N},-96^{\circ} 93.50^{\prime} \mathrm{W}$ $19^{\circ} 47.88^{\prime} \mathrm{N},-96^{\circ} 40.02^{\prime} \mathrm{W}$ Yucatan $20^{\circ} 51.37^{\prime} \mathrm{N},-89^{\circ} 11.70^{\prime} \mathrm{W}$ $20^{\circ} 33.03^{\prime} \mathrm{N},-89^{\circ} 54.73^{\prime} \mathrm{W}$
Dates (dd,mm,year)

01/03/2005; 30/07/2013

21/02/2005; 19/07/2013

07/06/2002; 10/05/2013

$31 / 03 / 2014$

$11 / 06 / 2002$

07/04/2014

$10 / 06 / 2002$

07/06/2002; 11/11/2007; 11/05/2013

$24 / 03 / 2009$

$03 / 04 / 2014$

08/06/2002; 04/04/2014

$02 / 04 / 2014$

$06 / 04 / 2014$

29/07/2007

$18 / 01 / 2018$

$26 / 03 / 2009$

23/07/2007

$10 / 06 / 2002 ; 27 / 07 / 2007$

$23 / 07 / 2018$

$30 / 07 / 2007$

16/07/2013;09/04/2014

28/03/2009

$24 / 07 / 2007$

$24 / 02 / 2005$

$26 / 02 / 2005 ; 21 / 07 / 2013$

$25 / 02 / 2005$

$25 / 07 / 2013$

$25 / 02 / 2005$

02/03/2005; 19/07/2018

03/03/2005

05/06/2002; 05/05/2016; 20/07/2018

03/03/2005

$04 / 03 / 2005$

05/03/2005; 06/04/2011;01/12/2014;08/05/2016

$$
\begin{gathered}
01 / 06 / 2002 \\
12 / 04 / 2011 \\
15 / 05 / 2014 \\
07 / 03 / 2005 ; 08 / 12 / 2014 \\
16 / 05 / 2014
\end{gathered}
$$

07/03/2005; 09/04/2011; 18/07/2018

$02 / 06 / 2002$

$06 / 06 / 2014$

$27 / 07 / 2013$

$28 / 02 / 2005 ; 28 / 07 / 2013$ 
We visited this locality in Jun 2002, May 2016, and June 2018 and during this visits we captured six females and 14 males. Tissue samples were deposited in the LBEM-UAMI with the following registration numbers: 020605PGY1- 020605PGY3; 050516PGY1- 050516PGY10; 200718PGY1- 200718PGY7. Specimens were captured individually between 22:00 and 24:30 hrs. Eight species of bats representing four different families were identified in this cave: two Emballonuridae (B. plicata, Saccopteryx bilineata), five Mormoopidae (M. megalophylla, $P$. davyi, P. gymnonotus, P. parnellii and P. personatus), and one Vespertilionidae (M. californicus).

In the three localities, the momoopid species $P$. fulvus was particularly abundant, and although the characteristics of the caves did not allow us to determine the size of their populations, we observed that in each case there were thousands of individuals. In the study area P. gymnonotus and $P$. fulvus are quite similar to each other (Figure 2), but their differences in size, as well as the forearm values and weight allow their correct separation easily (Table 2). Our genetic analyses also confirmed the identifications made based on morphometric caracteristics, and genetic distances obtained (Table 3), as well as the phylogenetic reconstruction (Figure 3), clearly separate $P$. fulvus from $P$. gymnonotus. Due to the rarity of the $P$. gymnonotus, we highlight the presence of pregnant females in May 2016 in the Cueva de Villa Luz and in the Agua Blanca State Park.

\section{Discussion}

The presence of $P$. gymnonotus in México, the northernmost part of its geographical distribution, was supported only by scattered records in over fifty years (Davis et al. 1964; Álvarez-Castañeda and Álvarez 1991a; lbañez et al. 2000; Guzmán-Soriano et al. 2013). The three locations reported here, in which we found $P$. gymnonotus, definitely reaffirm the presence of this species in the country.

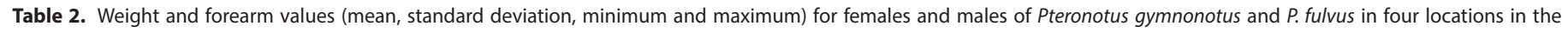
northernmost part of the distribution of $P$. gymnonotus.

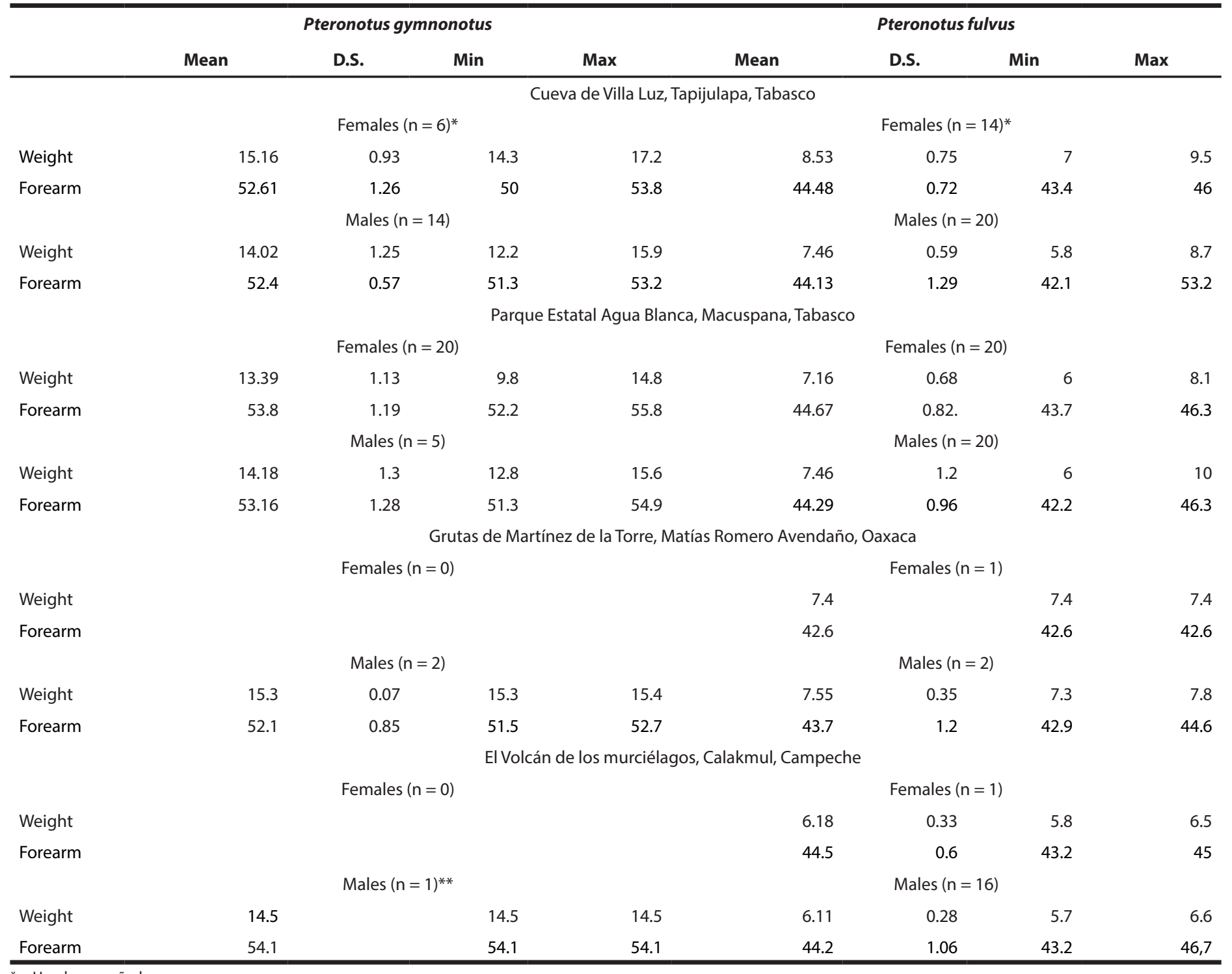

* $=$ Hembras preñadas.

** Datos obtenidos de Guzmán-Soriano et al. (2013). 


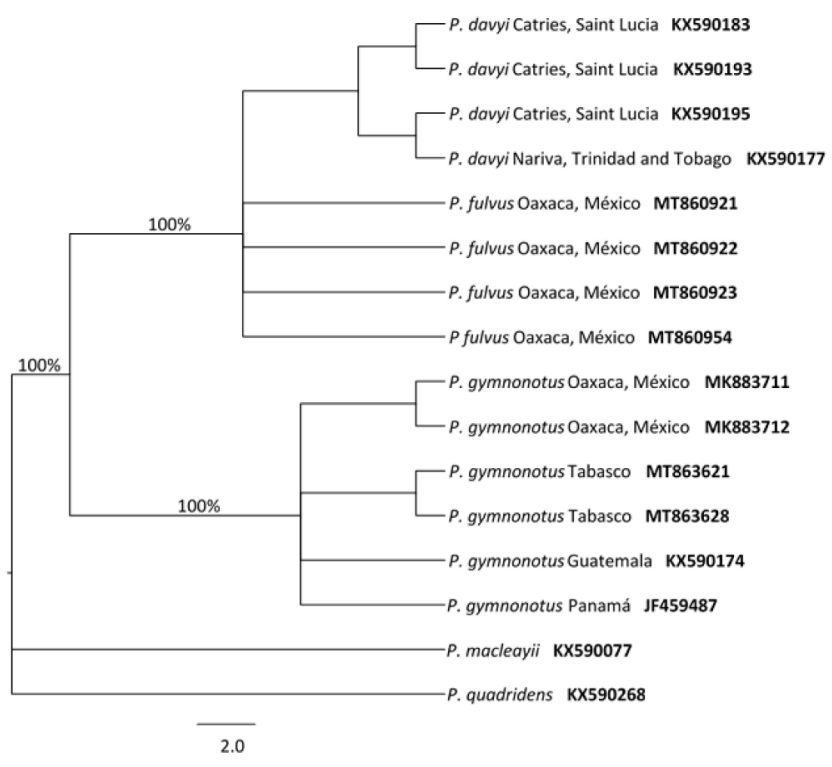

Figure 3. Phylogenetic reconstruction of mitochondrial data (COI) to confirm the identification of bats from Martínez de La Torre, Oaxaca (Genbank: MK883711 and MK883712) and Agua Blanca, Tabasco (Genbank: MT863621 and MT863628) as Pteronotus gymnonotus. Sequences of $P$. gymnonotus from Guatemala and Panama (Genbank: KX590174 and JF459487), P. fulvus from Oaxaca (Genbank: MT860921, MT860922, MT860923 and MT860954) and P. davyi from Saint Lucia and Trinidad and Tobago (Genbank : KX590183, KX590193, KX590197) were included for comparison. Sequences of $P$. macleayii and P. quadridens (Genbank: KX590077 and KX590268) were used as an external group. Values in branches indicate Bayesian posterior probabilities.

Parque Estatal Agua Blanca has been until now the locality with the largest number of specimens collected in México and most of Central America; only Deleva and Chaverri (2018) report a bigger roost for this species in Costa Rica. This locality is a protected natural area of 2,025 ha with tropical evergreen forest as the dominant vegetation type (Castro-Luna et al. 2007; Vargas 2012). According our observations $P$. gymnonotus seems to prefer to move and forage inside the gallery forest, a vegetation type that is also abundant in the area.

Our capture records at Grutas de Martínez de la Torre are important because this cave complex is located near the center of the Isthmus of Tehuantepec, $105 \mathrm{~km}$ South from the Gulf of México Coast and $134 \mathrm{~km}$ North from the Mexican Pacific Coast. This is an area that is well known for being a biogeographic barrier for many taxa (Mulcahy et al. 2006). In it, medium and low deciduous forests predominate, the kind of habitat in which Reid (1999) mentions the presence of $P$. gymnonotus in South America. The closest previous record corresponds to the Laguna Encantada, Veracruz, located $110 \mathrm{~km}$ to the North and we suggest that the Isthmus of Tehuantepec may have played an important role in allowing the expansion of $P$. gymnonotus northward until reaching the area of Los Tuxtlas, Veracruz. The absence of recent records in this area is probably related to the almost total loss of tall evergreen forests that the region has experienced in recent times (García-Romero et al. 2004; Taubert et al. 2018), and to the intensive use of the cave by the local population for ritual ceremonies (Münch 2012). This location is in the transitional area to the Pacific lowlands, a region in which individuals considerably larger than typical specimens of $P$. fulvus, and whose measures are very near to those of $P$. gymnonotus, have been occasionally recorded (Goodwin 1958, 1969; Smith 1972; Álvarez and Álvarez-Castañeda 1991b) suggesting suggesting possible hybridization between those species.

At Cueva de Villa Luz, Gordon and Rosen (1962) reported the presence of at least three large bat colonies, consisting mainly of bats from the Family Mormoopidae. The largest of these colonies is located approximately $150 \mathrm{~m}$ from the main entrance, a site with $32.3^{\circ} \mathrm{C}$ and a relative humidity of $85 \%$. In 2018, using a hand net, we captured two specimens of $P$. gymnonotus among thousands of $P$. fulvus individuals in this site.

Mormoopid bats are commonly found living syntopically with other members of the same family, as well as with species from other families (Smith 1972; Emmons and Feer 1997). P. gymnonotus, living in the northernmost part of its geographic range, is not the exception. Five families and thirteen species of bats have been recorded associated with this species: three emballonurids (B. io, B. plicata, and S. bilineata), three phyllostomids (C. brevicauda, D. rotundus, and L. aurita), five mormoopids (M. megalophylla, P. fulvus, $P$. mexicanus, P. personatus, and P. psilotis), one natalid ( $N$. mexicanus) and one vespertilionid (M. californicus; Gordon and Rosen 1962; Palacios Vargas 2009; Guzman-Cornejo et al. 2012; this paper).

In the caves visited by us, we always found P. gymnonotus associated with P. davyi. Pavan and Tavares (2020) observed that $P$. gymnonotus is rarely found syntopically with other species of naked-backed bats, with only a few sparse records of this situation. However, in the northernmost part of its geographic range, this species usually has been reported to co-occur with P. fulvus (Davis et al. 1964; lbáñez et al. 2000; this paper).

Our data are indicative of the presence of a reproductive population of $P$. gymnonotus in the southeast of México. We found pregnant females in May 2016 in the Cueva de Villa Luz and in the Agua Blanca State Park. These females may belong to the same reproductive population, since both places are only $38 \mathrm{~km}$ apart. This population seems to be a resident one, because regardless of the year, our samples have covered the months of March to July, plus one in December, and we have always registered the presence of P. gymnonotus in the area.

Table 3. Genetic distance data between $\mathrm{CO}$ sequences of individuals of $P$. gymnonotus (Pgy), P. fulvus (Pfu) and P. davyi (Pda). Oaxaca (O), Tabasco (T), Guatemala (G), Antillas Menores (A). Data was obtained using the Kimura 2 Parameters (K2P) model.

\begin{tabular}{lrrrrr}
\hline & \multicolumn{1}{c}{ Pgy-O } & \multicolumn{1}{c}{ Pgy-T } & Pgy-G & Pfu-O & Pda-A \\
\hline Pgy-O & - & & & & \\
Pgy-T & 1.1 & - & & & \\
Pgy-G & 0.7 & 0.3 & - & & \\
Pfu-O & 8.6 & 8.1 & 7.8 & - & \\
Pda-A & 9.0 & 8.6 & 8.2 & 0.05 & - \\
\hline
\end{tabular}


Beside this, all other P. gymnonotus specimens captured in our field trips were adults, without an evident reproductive status and only one juvenile male was registered in July for Cueva de Villa Luz. This suggests that P. gymnonotus in its northernmost geographic distribution has a monestral reproductive cycle, probably with births between late June - early July, data that are in agreement with the report of pregnant females in the same month in Nicaragua, El Salvador and México (Jones et al. 1971; Hayssen et al. 1993; Ibañez et al. 2000).

Pteronotus gymnonotus is an obligate cave-dweller bat. In Costa Rica colonies have been reported with more than 500 individuals in several karstic caves (Deleva and Chaverri 2018); also large assemblages of many thousands of individuals have been observed in karstic localities in northeastern Brazil (Rocha et al. 2011; Feijó and Rocha 2017; Vargas-Mena et al. 2018). In México, this species is not abundant, with only very few specimens collected in karstic caves in the Parque Estatal Agua Blanca, El Volcán de los Murciélagos and in the Grutas de Martínez de la Torre (Guzmán-Soriano et al. 2013; this paper). It is noteworthy that in México some records are from two non-karstic caves, Laguna Encantada and Villa Luz, both of volcanic origin.

There are studies mentioning that $P$. gymnonotus is more abundant in dry and semi-open environments (Pavan and Tavares 2020), but in México this species has been recorded in the ecoregion called warm-humid tropical forest located in the low areas along the Gulf of México and in the North and East of the Isthmus of Tehuantepec. Two earlier reports (Álvarez-Castañeda and Álvarez 1991a; Guzmán-Soriano et al.2013) recorded this species in moist tropical deciduous forests and we found it associated with large remnants of tropical evergreen forest and especially in gallery forests. Finding P. gymnonotus in this type of environment is probably due to the fact that insectivorous bats often use riparian forests as feeding refuges due to the high availability of insects and the facilities they offer for flight and echolocation (Grindal et al. 1999; Robinson et al. 2002; Hagen and Sabo 2011).

During the last fifty years the processes of deforestation and habitat fragmentation have been very important in southeastern México, the northernmost geographic distribution range for $P$. gymnonotus. In México, the warmhumid tropical forests include the high and medium evergreen and sub-evergreen forests, which are found almost exclusively in the plains of the Gulf of México, the South and East of the Yucatán Peninsula and the East of Chiapas. It is estimated that these forests have been reduced by more than $80 \%$ in recent years (Challenger and Soberón 2008) at an annual rate of deforestation between 1993 and 2007 of $0.83 \%$, although this deforestation rate tends to decrease in the area (Kolb and Galicia 2012). Currently these types of forests are only found in the most rugged terrain, but they also continue to be affected by factors such as selective timber extraction, firewood collection, grazing or man-induced fires. Bats have a high tolerance to landscape modification due to their ability to fly and the ease with which they can cross open areas (Medellín et al. 2000; Castro-Luna et al. 2007). In this context, we highlight the need for more precise information about the distribution, conservation status, and ecology of this species.

\section{Acknowledgements}

We want to dedicate this paper to all the students that with their everyday efforts made possible for many years all the fieldwork trips to study bats across the country. We are grateful to the regional and local authorities that allowed our research and collection of specimens and all the people that generously gave their attention and facilities to us and made our work so much easier. Finally, we also thank K. Rylander, R. D. Owen and two anonymous reviewers for their suggestions and revisions to improve this manuscript. Our works about $P$. gymnonotus and other mormoopid bats species were supported by the División de Ciencias Biológicas y de la Salud de la Universidad Autónoma Metropolitana-Iztapalapa and by the Consejo Nacional de Ciencia y Tecnología (CONACYT) for RLW (CB-2009-01/128459), and for LMGC (UAM-PTC-449-PROMEP, CB-2014-01/243138).

\section{Literature cited}

Álvarez-Castañeda, S. T., AND T. Álvarez. 1991a. Los murciélagos de Chiapas. Instituto Politécnico Nacional, Escuela de Ciencias Biológicas. Ciudad de México, México.

Álvarez-Castañeda, S. T., AND T. Álvarez. 1991b. Notas sobre el estado taxonómico de Pteronotus davyi en Chiapas y de Hylonycteris en México. Mammalia: Chiroptera. Anales de la Escuela Nacional de Ciencias Biológicas 34:223-229.

Álvarez-Castañeda, S. T., T. Álvarez, and N. González-Ruiz. 2017. Guía para la identificación de los mamíferos de México. Johns Hopkins University Press. Baltimore. U.S.A.

Anonymous. 2010. Lineamientos para la conducción ética de la investigación, docencia y difusión. División de Ciencias Biológicas y de la Salud, Universidad Autónoma Metropolitana, Iztapalapa. Ciudad de México, México.

Barragán, F., C. Lorenzo, A. Morón, M. Briones-Salas, and S. LóPEZ. 2010. Bat and rodent diversity in a fragmented landscape on the Isthmus of Tehuantepec, Oaxaca, México. Tropical Conservation Science 3:1-16.

Castro-Luna, A. A. 1999. Composición y abundancia de la comunidad de murciélagos (Mammalia: Chiroptera) del Parque Estatal Agua Blanca, Macuspana, Tabasco. Universidad y Ciencia 15:57-68.

Castro-Luna, A. A., V. J. Sosa, and G. Castillo-Campos. 2007. Bat diversity and abundance associated with the degrees of secondary succession in a tropical forest mosaic in southeastern México. Animal Conservation 10:219-228.

Cavazos, T., and S. Hastenrath. 1990. Convection and rainfall over México and their modulation by the Southern Oscillation. International Journal of Climatology 10:377-386.

cCa Comisión para la Cooperación Ambiental de América del Norte, CONABio Comisión Nacional para el Conocimiento y Uso de la Biodiversidad, INEGI Instituto Nacional de Estadística Y Geografía, INE Instituto Nacional de Ecología. 2010. Atlas de Biodiversidad, Ecorregiones terrestres de México Nivel I. 
Challenger, A., And J. Soberón. 2008. Los ecosistemas terrestres. Pp. 87-108, in Conocimiento Actual de la Biodiversidad México. Capital natural de México. (Soberón J., G. Halffter, and J. Llorente B., comps.). Comisión Nacional para el Conocimiento y Uso de la Biodiversidad. Ciudad de México, México.

Chambers, C. L., S. A. Cushman, A. Medina-Fitoria, J. MartínezFonseca, and M. Chávez Velásquez. 2016. Influences of scale on bat habitat relationships in a forested landscape in Nicaragua. Landscape Ecology 31:1299-1318.

Coates, R., I. Ramírez-Lucho, and A. González-Christen. 2017. Una lista actualizada de los murciélagos de la región de Los Tuxtlas, Veracruz. Revista Mexicana de Biodiversidad 88: 349-357.

Davis, W. B., D. C. Carter, and R. H. Pine. 1964. Noteworthy records of Mexican and Central American bats. Journal of Mammalogy 45:375-387.

Deleva, S., And G. Chaverri. 2018. Diversity and conservation of cave-dwelling bats in the Brunca Region of Costa Rica. Diversity 10:43.

EisenberG, J. F., And K. H. Redford. 1999. Mammals of the Neotropics: Ecuador, Peru, Bolivia, Brazil. The Central Neotropic. University of Chicago Press. Chicago, U.S.A.

Emmons, L. H., And F. Feer. 1997. Neotropical Rainforest Mammals: A Field Guide, Second edition. University of Chicago Press. Chicago, U.S.A

Escobedo, M. L. A., L. León Paniagua, J. Arroyo-Cabrales, and O. Polanco. 2005. Diversidad y abundancia de los mamíferos de Yaxchilán, municipio de Ocosingo, Chiapas. Pp. 283-298, in Contribuciones mastozoológicas en homenaje a Bernardo Villa. (Sánchez-Cordero V., and Medellín R. A. eds.). Instituto de Biología e Instituto de Ecología, UNAM; Comisión Nacional para el Conocimiento y Uso de la Biodiversidad. Ciudad de México, México.

Estrada, A., R. Coates-Estrada, and D. Meritt. 1993. Bat species richness and abundance in tropical rain forest fragments and in agricultural habitats at Los Tuxtlas, México. Ecography 16:309-318.

Feijo, A. e P. A. Rocha. 2017. Morcegos da Estação Ecológica Aiuaba, Ceará, nordeste do Brasil: Uma unidade de proteção integral na Caatinga. Mastozoología Neotropical 24:333-346.

GBIF Global Biodiversity Information Facility. 2020. GBIF. org. 21 May 2020. GBIF Occurrence Download https://doi. org/10.15468/dl.qa6uh3.

GamboA, V. J., AND I. Ku. 1998. Descripción de la cueva "Las Sardinas", Villa Luz, Tabasco, México. Mundos subterráneos 9:51-54.

García, E. 1988. Modificaciones al sistema de clasificación climática de Köppen. Offset Larios, México D.F.

García-Romero, A. 2003. Vegetación 2000, esc. 1:250,000. Atlas regional del Istmo de Tehuantepec, III.13. Instituto de Geografía, UNAM, México.

García-Romero A., O. Oropeza-Orozco, and L. Galicia-Sarmiento. 2004. Land-use systems and resilience of tropical rain forests in the Tehuantepec Isthmus, México. Environmental Management 34:768-785.

González-Christen, A. 2008. La diversidad alfa, beta y gamma de la mastofauna de la sierra de Santa Marta, Veracruz, México. Pp.103-123, in Avances en el estudio de los mamíferos de México II. Publicaciones especiales (C. Lorenzo, E. Espinoza, and J. Ortega, eds.). Asociación Mexicana de Mastozoología,
A. C., CIBNOR, , ECOSUR, INP, UAM, UNICACH, Universidad Veracruzana. México.

Goodwin, G. G. 1969. Mammals from the state of Oaxaca, México, in the American Museum of Natural History. Bulletin American Museum of Natural History 141:1-270.

Goodwin, G. G., T. B. Macdougall, and J. R. Marcus, JR. 1958. Two new mammals from México. American Museum Novitates 1871:1-3.

Gordon, M. S., ANd D. E. Rosen. 1962. A cavernicolous form of the poeciliid fish Poecilia sphenops from Tabasco, México. Copeia 360-368.

Grindal, S. D., J. L. Morissette, And R. M. Brigham. 1999. Concentration of bat activity in riparian habitats over an elevational gradient. Canadian Journal of Zoology 77:972-977.

Guzmán-Soriano, D., J. A. Vargas-Contreras, J. D. Cú-Vizcarra, S. G. Escalona, G. G. Retana, C. A. González, T. J. A. Benítez, J. Arroyo-Cabrales, C. J. C. Puc, and C. E. Victoria. 2013. Registros notables de mamíferos para Campeche, México. Acta Zoológica Mexicana 29:269-286.

Guzmán-Cornejo, C., R. Paredes-León, M. B. Labruna, S. Nava, and J. M. Venzal. 2012. Molecular identification and description of the female of Nothoaspis reddelli. Ixodida: Argasidae. from a cave in southeastern México. Journal of Parasitology 98:918-923.

Hagen, E. M., and J. L. Sabo. 2011. A landscape perspective on bat foraging ecology along rivers: does channel confinement and insect availability influence the response of bats to aquatic resources in riverine landscapes? Oecologia 166:751-60.

Handley, C. O. 1966. Checklist of the mammals of Panama. Pp. 753-795 in Ectoparasites of Panama (Wenzel, R. L., and V. J. Tipton, eds.). Field Museum of Natural History. Chicago, U.S.A.

Handley, C. O. 1976. Mammals of the Smithsonian Venezuelan Project. Brigham Young University Science Bulletin 20:1-89.

Hayssen, V., A. Tienhoven, And A. Tienhoven. 1993. Asdell's patterns of mammalian reproduction: a compendium of species-specific data. Cornell University Press. Ithaca, U.S.A.

Hose, L. D., And J. A. Pisarowicz. 1999. Cueva de Villa Luz, Tabasco, México: reconnaissance study of an active sulfur spring cave and ecosystem. Journal of Cave and Karst Studies 61:13-21.

Ibáñez, C., R. López-Wilchis, J. Juste, and M. A. León-Galván. 2000. Echolocation calls and a noteworthy record of Pteronotus gymnonotus (Chiroptera, Mormoopidae) from Tabasco, México. The Southwestern Naturalist 45:345-347.

IGGUNAM, Instituto de Geografía, UNAM. 2007. Vegetación. Nuevo Atlas Nacional de México, Sección Naturaleza y Ambiente, Carta NA IV 1. Instituto de Geografía, Universidad Nacional Autónoma de México.

INEGi, Instituto Nacional de Estadística y Geografía. 2008. Conjunto de Datos Vectoriales, Unidades climáticas. Escala: 1:1 000 000, Instituto Nacional de Estadística y Geografía. Aguascalientes, México. https://www.inegi.org.mx/app/biblioteca/ ficha.html?upc $=702825267568$

Ivanova, N. V., J. R. DewaARd, AND P. D. N. Hebert. 2006. An inexpensive, automation-friendly protocol for recovering highquality DNA. Molecular Ecology Notes 6:998-1002.

Jones, J. K., J. D. Smith, AND R. W. Turner. 1971. Noteworthy records of bats from Nicaragua, with a checklist of the chirop- 
teran fauna of the country. Occasional Papers of the Museum of Natural History, the University of Kansas 17:1-35.

Kearse, M., R. Moir, A.Wilson, S. Stones-Havas, M. Cheung, S. Sturrock, S. Buxton, A. Cooper, S. Markowitz, C. Duran, T. Thierer, B. Ashton, P. Mentuies, And A. Drummond. 2012. Geneious Basic: an integrated and extendable desktop software platform for the organization and analysis of sequence data. Bioinformatics 28:1647-1649.

Kolb, M., And L. Galicia. 2012. Challenging the linear forestation narrative in the Neo-tropic: Regional patterns and processes of deforestation and regeneration in southern México. The Geographical Journal 178:147-161.

Kunz, T. H., R. Hodgkison, And C. Weise. 2009. Methods of capturing and handling bats. Pp. 5-35, in Ecological and behavioral methods for the study of bats (Kunz T. H, and S. Parsons, eds.) . The Johns Hopkins University Press. Michigan, U.S.A.

LaVAL, R. K., And B. Rodríguez-Herrera. 2002. Murciélagos de Costa Rica: Bats. Instituto Nacional de Biodiversidad. Santo Domingo, Costa Rica.

Lopera-Barrero, N. M., J. A. Povh, R. P. Ribeiro, P. C. Gomes, C. B. Jacometo, AND L. T. D. Silva. 2008. Comparación de protocolos de extracción de ADN con muestras de aleta y larva de peces: extracción modificada con cloruro de sodio. Ciencia e Investigación Agraria 35:77-86.

Lorenzo, C., A. Carrillo-Reyes, M. Gómez-Sánchez, A. Velázquez, And E. Espinoza. 2011. Diet of the endangered Tehuantepec jackrabbit, Lepus flavigularis. Therya 2:67-76.

McCarthy, T. J. 1987. Distributional records of bats from the Caribbean lowlands of Belize and adjacent Guatemala and México. Pp. 137-162 in Studies in neotropical mammalogy: essays in honor of Phillip Hershkovitz (Patterson, B. D., and R. M. Timm, eds). Fieldiana Zoology New Series 39:VII+1-506.

Medellín, R. A. 1993. Estructura y diversidad de una comunidad de murciélagos en el trópico húmedo mexicano. Pp. 333-354 in Avances en el estudio de los mamíferos de México (Medellin, R. A., and Ceballos, G.. eds). Asociación Mexicana de Mastozoología. Publicaciones Especiales 1. México.

Medellín, R. A. 1994. Mammal diversity and conservation in the Selva Lacandona, Chiapas, México. Conservation Biology 8:780-799.

Medellín, R. A., H. T. Arita, and O. Sánchez. 2008. Identificación de los murciélagos de México, clave de campo, Segunda Edición. Instituto de Ecología, UNAM. México.

Medellín, R. A., G. Urbano-Vidales, O. Sanchez-Herrera, G. Tellez-Giron, And H. Arita. 1986. Notas sobre murcielagos del este de Chiapas. Southwestern Naturalist 31:532-535.

Medellín, R. A., M. Equinua, And M. A. Amín. 2000. Bat diversity and abundance as indicators of disturbance in neotropical rainforest. Conservation Biology 14:1666-1675.

Moreno-Jiménez, V., L. M. Gama-Campillo, A. Romero-García, S. Ochoa-Gaona, W. M. Contreras-Sánchez, N. D. C. Jiménez-Pérez, and E. E. Mata-Zayas. 2019. Características del paisaje y su relación con la diversidad y estructura de la vegetación ribereña del sureste de México. Acta Botánica Mexicana 126:1-20.

Mulcahy, D. G., B. H. Morrill, And J. R. Mendelson III. 2006. Historical biogeography of lowland species of toads Bufo across the Trans-Mexican Neovolcanic Belt and the Isthmus of Tehuantepec. Journal of Biogeography 33:1889-1904.
Münch Galindo, G. G. 2012. La magia tuxteca. Instituto de Investigaciones Antropológicas, UNAM. México.

Palacios-Vargas, J. G. 2009. Los estudios bioespeleológicos de la cueva de las sardinas y sus perspectivas. Mundos Subterráneos 20:22-26.

Pavan, A. C., And G. Marroig. 2017. Timing and patterns of diversification in the Neotropical bat genus Pteronotus. Mormoopidae. Molecular Phylogenetics and Evolution 108:61-69.

Pavan, A. C., And C. V. Tavares. 2020. Pteronotus gymnonotus. Chiroptera: Mormoopidae. Mammalian Species 52:40-48.

Plasencia-Vázquez, A. H., G. Escalona-Segura, J. D. Cú-Vizcarra, K. P. Borges-Jesús, A. Serrano Rodríguez, Y. Ferrer-Sánchez, and J. A. Vargas-Contreras. 2020. Diversidad de murciélagos en la selva baja inundable del sureste de México. Revista de Biología Tropical 68:623-640.

Plath, M., M. Tobler, R. Riesch, F. G. García de León, and I. SchLUPP. 2006. Evolutionary biology in Cueva Villa Luz: Ichthyological research in a sulfidic cave in Tabasco. Association for Mexican Cave Studies. AMCS. Activities Newsletter 69:64-68.

PosadA, D. 2008. jModelTest: Phylogenetic Model Averaging. Molecular Biology and Evolution 25:1253-1256.

Reid, F. A. 2009. A field guide to the mammals of Central America and southeast México, 2nd edition. Oxford University Press. New York, U.S.A.

Robinson, C. T., K. Tockner, AND J. V. WARD. 2002. The fauna of dynamic riverine landscapes. Freshwater Biology 47:661-677. Rocha, P. A., J. A. da Feijó, J. S. Mikalauskas, and S. F. Ferrari. 2011. First records of mormoopid bats. Chiroptera, Mormoopidae from the Brazilian Atlantic Forest. Mammalia 75:295-299.

Ronquist, F., M. Teslenko, P. V. D. Mark, D. L. Ayres, A. Darling, S. Höhna, B. Larget, L. Liu, M. A. Suchard, and J. P. Huelsenbeck. 2012. MrBayes 3.2: Efficient Bayesian phylogenetic inference and model choice across a large model space. Systematic Biology 61:539-542.

Santos-Moreno, A., and E. Ruiz-Velásquez. 2007. Diversidad de mamíferos de la región de Nizanda, Juchitán, Oaxaca, México. Therya 2:155-168.

Sánchez-Hernandez, C., And A. M. L. Romero. 1995. Los murcielagos de Tabasco y Campeche una propuesta para su conservación. Cuadernos de Instituto de Biología 24, Universidad Nacional Autónoma de México, Ciudad de México, México.

Semarnat, Secretaría de Medio Ambiente y Recursos Naturales. 2010. Norma Oficial Mexicana NOM-059, Protección ambiental-especies nativas de México de flora y fauna silvestres. Categorías de riesgo y especificaciones para su inclusión, exclusión o cambio. Lista de especies en riesgo, Diario oficial de la Federación 2008. Ciudad de México, México.

Sikes, R. S, and Animal Care and Use Committee of the American Society of Mammalogists. 2016. Guidelines of the American Society of Mammalogists for the use of wild mammals in research and education. Journal of Mammalogy 97:663-688.

Sıмmons, N. B. 2005. Order Chiroptera. Pp. 312-529 in Mammal species of the world, 3rd edition (Wilson, D. E, and D. M. Reeder, eds). The Johns Hopkins Press. Baltimore, U.S.A.

Simmons, N. B., ANd T. M. Conway. 2001. Phylogenetic relationships of mormoopids bats. Chiroptera: Mormoopidae based on morphological data. Bulletin of the American Museum of Natural History 258:1-97. 
Sмıтн, J. D. 1972. Systematics of the chiropteran family Mormoopidae. Miscellaneous Publications, University of Kansas, Museum of Natural History 56:1-132.

SMiтH, J. D. 1977. On the nomenclatural status of Chilonycteris gymnonotus Natterer, 1843. Journal of Mammalogy 58:245-246.

Solari, S. 2019. Pteronotus gymnonotus. In The IUCN Red List of Threatened Species. Version 2020.2. Retrieved from http:// dx.doi.org/10.2305/IUCN.UK.2019-1.RLTS.T18706A22077065.

Tamura, K., D. Peterson, N. Peterson, G. Stecher, M. Nel, and S. Kumar. 2011. MEGA5: Molecular Evolutionary Genetics Analysis using maximum likelihood, evolutionary distance, and maximum parsimony methods. Molecular Biology and Evolution 28:2731-2739.

Taubert, F., R. Fischer, J. Groeneveld, S. Lehmann, M. S. Müller, S. Rödig, S., T. WIEGAND, AND A. Huth. 2018. Global patterns of tropical forest fragmentation. Nature 554:519-522

Vargas-Mena, J. C., E. C. Schmidt, and H. B. Rodriguez. 2018. Diversity of cave bats in the Brazilian tropical dry forest of Rio Grande do Norte state. Mastozoologia Neotropical 18:e20170417.

VArGas, M. F. 2012. SEMARNAT, ed. Áreas Naturales Protegidas de México con Decretos Estatales, Volumen 2. 1ra. edición. Ciudad de México, México.

Vidal Cepeda, R., A.l. Cabrera Sánchez, and S. E. Menchaca. 2007. Climas: Según sistema de clasificación climática de Köppen modificado por Enriqueta García. Nuevo Atlas Nacional de México, Sección Naturaleza y Ambiente, Carta NA IV 13. Instituto de Geografía, Universidad Nacional Autónoma de México.

Vidal Cepeda, R., and G. Matias Ramírez. 2003. Climas, esc. 1:250,000. Atlas regional del Istmo de Tehuantepec, III.8. Instituto de Geografía, UNAM. Ciudad de México, México.

Vılla-R., B. 1966. Los murciélagos de México. Instituto de Biología, Universidad Autónoma de México. Ciudad de México, México.

Villegas-Patraca, R., O. Muñoz-Jiménez, and J. L. Aguilar-López. 2020. Diversity and conservation of bats in a private protected area of southern México. Therya Notes 1:95-100.

Associated editor: Robert Owen

Submitted: October 6, 2020; Reviewed: November 11,2020;

Accepted:March 29, 2021; Published on line:April 15, 2021. 
